\title{
Uji Efektivitas Cangkang Keong Mas (Pomacea canaliculata L.) Sebagai Biosorben Dalam Menyerap Logam Berat Merkuri (Hg)
}

\author{
Risna Mauriza ${ }^{1}$, Husnawati Yahya ${ }^{2}$, T.M. Ashari \\ ${ }^{1,2,3}$ Prodi Teknik Lingkungan, Fakultas Sains dan Teknologi, Universitas Islam Negeri Ar-Raniry, Banda Aceh \\ *Koresponden email: husna.83@ar-raniry.ac.id
}

Diterima: 20 Agustus 2020

Disetujui: 2 Oktober 2020

\begin{abstract}
Adsorbent is one of the effective solutions to reduce the $\mathrm{Hg}$ metal content. The golden snail is a pest for agricultural and contains high of calcium carbonate. However, calcium carbonate can be used as an adsorbent. This study aimed to examine the effectiveness of golden snail shell powder in absorbing $\mathrm{Hg}$ metal. This research is a quantitative study consisting of dependent variables and independent variables. The dependent variable involved a concentration of $10 \mathrm{ppm}$ mercury, and $100 \mathrm{rpm}$ stirring time speed while the independent variable included of variations in powder mass and stirring time. The mass of golden snail powder used those are $0 \mathrm{gr}, 5 \mathrm{gr}, 10 \mathrm{gr}, 15 \mathrm{gr}$, and $20 \mathrm{gr}$ with a variation of stirring time for 15 minutes and 30 minutes for each sample of $\mathrm{Hg}$ metals. Each $\mathrm{Hg}$ sample was used at a concentration of $10 \mathrm{ppm}$. The calculation results obtained that the effectiveness of golden snail shell powder in absorbing $\mathrm{Hg} 10 \mathrm{ppm}$ was the mass of 20 grams of golden snail powder with a stirring time of 30 minutes that was equal to $99.87 \%$ with the result of a decrease in concentration of $10 \mathrm{ppm} \mathrm{Hg}$ to $0.01 \mathrm{Hg}$ ppm.
\end{abstract}

Keywords: adsorbent, golden snail shell, mercury, stirring time, shell mass

\begin{abstract}
Abstrak
Salah satu cara untuk mengurangi kandungan logam $\mathrm{Hg}$ dapat dilakukan dengan penggunaan adsorben. Kalsium karbonat dapat dijadikan sebagai adsorben. Keong mas merupakan salah satu hama pertanian yang mengandung banyak kalsium karbonat. Penelitian ini bertujuan untuk menguji keefektifan serbuk cangkang keong mas dalam menyerap logam $\mathrm{Hg}$. Penelitian ini merupakan penelitian kuantitatif yang terdiri dari variabel terikat dan variabel bebas. Variabel terikat terdiri dari konsentrasi $10 \mathrm{ppm}$ merkuri dengan kecepatan waktu pengadukan $100 \mathrm{rpm}$. Sedangkan variabel bebas terdiri dari variasi massa serbuk dan waktu pengadukan. Massa serbuk keong mas yang digunakan yaitu 0 gr; 5 gr; 10 gr; 15 gr dan 20 gr dengan variasi waktu pengadukan selama 15 menit dan 30 menit untuk tiap-tiap sampel Hg. Tiap - tiap sampel $\mathrm{Hg}$ yang digunakan dengan konsentrasi $10 \mathrm{ppm}$. Berdasarkan hasil perhitungan didapatkan hasil efektivitas serbuk cangkang keong mas dalam menyerap $\mathrm{Hg} 10 \mathrm{ppm}$ adalah pada massa 20 gr serbuk keong mas dengan waktu pengadukan 30 menit yaitu sebesar 99,87\% dengan hasil penurunan konsentrasi $\mathrm{Hg} 10$ ppm menjadi $\mathrm{Hg} 0,01 \mathrm{ppm}$.
\end{abstract}

Kata Kunci: adsorben, cangkang keong mas, merkuri, waktu pengadukan, massa serbuk

\section{Pendahuluan}

Bijih logam berat sering digunakan manusia untuk keperluan sehari-hari. Salah satu bijih logam berat yaitu Merkuri $(\mathrm{Hg})$ [1]. Merkuri atau raksa $(\mathrm{Hg})$ merupakan salah satu jenis logam berat yang banyak diperoleh dari bebatuan dan juga banyak dipakai dalam aktivitas penambangan [1]. Merkuri yang dihasilkan dari aktivitas penambangan dapat mencapai 10.000 ton merkuri/tahunnya. Keadaan ini juga berpengaruh terhadap kesehatan para penambang. Pekerja tambang dapat terpapar merkuri dengan kadar konsentrasi yang berbeda-beda. Seandainya para pekerja tambang terpapar merkuri pada kadar 0, 05 $\mathrm{mg} / \mathrm{m} 3$ dapat menyebabkan neurasthenia atau sering dikenal dengan lemahnya sistem saraf secara mekanis dan jika terpapar lebih dari $0,05 \mathrm{mg} / \mathrm{m}^{3}$ dapat mengakibatkan kekejangan pada otot (tremor).

Merkuri banyak digunakan sebagai bahan dasar kosmetik tertentu, namun karena efek yang ditimbulkan sangat berbahaya bagi kesehatan, maka logam merkuri harus dikurangi kadarnya di lingkungan. Upaya yang sering digunakan adalah fitoremediasi dan juga penggunaan adsorben [2]. Biosorben merupakan salah satu upaya pemanfaatan bahan-bahan alami dalam menyerap beberapa senyawa kimia yang sudah mencemari lingkungan [3]. Banyak penelitian bahan alami dari beberapa cangkang hewan yang dapat dijadikan biosorben. Referensi [4] menyatakan bahwa cangkang keong mas banyak kandungan kalsium karbonat yang bermanfaat dalam menyerap beberapa pencemar di alam salah 
satunya logam berat. Sebelumnya telah ada penelitian oleh ref. [5] tentang kalsium karbonat yang terdapat pada kerang yang mampu menjernihkan air serta menyerap logam besi, mangan serta logam lainnya. Ref. [6] juga melaporkan penggunaan serbuk cangkang keong mas konsentrasi $10 \%$ dengan waktu kontak selama 20 jam mampu mengurangi logam tembaga $(\mathrm{Cu})$ dengan efisiensi penyerapan mencapai 99,98\%.

Menurut ref. [7] kitosan cangkang keong mas dapat menyerap logam Fe pada air sumur sebanyak 87,54\%. Selain itu, ref. [8] juga melaporkan bahwa kitosan cangkang udang seberat 0, 375 gr dapat menyerap logam $\mathrm{Cr}$ sebesar $98,44 \%$. Sedangkan kitosan cangkang udang seberat 0,5 gr dapat mengurangi logam Fe sebesar 99,21\%, mengurangi logam $\mathrm{Ni}$ sebesar 58,62\% (kitosan 0,375 gr), logam Cu sebesar $99,95 \%$ (kitosan 0,375 gr) dan logam $\mathrm{Zn}$ sebesar 56\% (kitosan 0,5 gr). Penelitian ini bertujuan untuk mengetahui massa serbuk cangkang keong mas (Pomacea canaliculata L) yang efektif dalam menyerap logam berat merkuri $(\mathrm{Hg})$ serta pengaruh waktu pengadukan terhadap penurunan konsentrasi logam merkuri $(\mathrm{Hg})$.

\section{Metodologi Penelitian}

\section{Tempat dan Waktu Penelitian}

Cangkang keong mas diperoleh dari beberapa keong mas yang hidup di sawah pada daerah Tungkop, Aceh Besar. Penelitian ini dilaksanakan pada tanggal 6 Agustus 2019 - 15 Oktober 2019. Perlakuan pengujian sampel dilakukan di Laboratorium Baristand, Banda Aceh.

\section{Alat dan Bahan}

Alat dan bahan yang digunakan dalam penelitian ini adalah AAS (Atomic Absorption Spectrometer) Shimadzu 6800AA, magnetic stirrer ZZKD, oven, gelas ukur $100 \mathrm{ml}$, pipet volume, timbangan analitik, labu ukur $100 \mathrm{ml}$, corong, botol semprot, erlenmeyer $250 \mathrm{ml}$ ayakan 100 mesh, blender elektrik, cangkang keong mas (Pomacea canaliculata L), akuades, dan larutan induk merkuri 1000 ppm (SNI 6989. 78: 2011), HNO3 pekat dan kertas saring.

\section{Metode Penelitian}

Penelitian ini menggunakan variabel terikat dan variable bebas dimana variable terikat terdiri dari konsentrasi $10 \mathrm{ppm}$ merkuri. Sedangkan variabel bebas terdiri dari variasi massa serbuk cangkang keong mas. Masing-masing variasi massa serbuk cangkang keong mas yang digunakan adalah $\mathrm{V} 1=0$ gr serbuk cangkang keong mas dalam $100 \mathrm{ml}$ larutan; V2= 5 gr serbuk cangkang keong mas dalam $100 \mathrm{ml}$ larutan; V3= 10 gr serbuk cangkang keong mas dalam 100 ml larutan; V4= 15 gr serbuk cangkang keong mas dalam $100 \mathrm{ml}$ larutan dan V5= 20 gr serbuk cangkang keong mas dalam $100 \mathrm{ml}$ larutan. Variasi lama waktu pengadukan untuk setiap sampel perlakuan adsorben yaitu 15 menit dan 30 menit.

\section{Preparasi Cangkang Keong Mas}

Cangkang keong mas dibersihkan lalu dicuci dengan air kemudian cangkang tersebut ditumbuk atau diblender sampai halus dan diayak dengan ayakan 100 mesh. Setelah diayak serbuk cangkang keong mas dimasukkan kedalam oven pada suhu $110^{\circ} \mathrm{C}$ selama 3 jam [9].

\section{Pembuatan Larutan Standar $\mathrm{Hg} 10$ ppm}

Larutan standar $\mathrm{Hg} 10 \mathrm{ppm}$ dibuat dengan menggunakan $1 \mathrm{ml}$ larutan induk $\mathrm{Hg} 1000$ ppm, kemudian dimasukkan kedalam labu ukur $100 \mathrm{ml}$ dan diencerkan menggunakan aquadest hingga batas tera, sehingga didapatkan larutan $\mathrm{Hg} 10$ ppm [10].

\section{Proses Penyerapan $\mathrm{Hg}$}

Proses penyerapan $\mathrm{Hg}$ dilakukan setelah membuat larutan standar logam merkuri dengan konsentrasi $10 \mathrm{ppm}$ dari larutan induk $1000 \mathrm{ppm}$ dengan $100 \mathrm{ml}$ akuades untuk tiap-tiap sampel [10]. Serbuk cangkang keong mas yang telah halus ditambahkan kedalam setiap perlakuan berturut-turut sebanyak 0 gr; 5 gr; 10 gr; 15 gr; dan 20 gr. Kemudian serbuk keong mas yang telah ditambahkan kedalam larutan diaduk menggunakan magnetic stirrer dengan kecepatan putaran $100 \mathrm{rpm}$ selama 15 menit untuk perlakuan pertama pada tiap-tiap sampel. Sedangkan untuk perlakuan kedua larutan $10 \mathrm{ppm}$ merkuri dibuat kembali dan ditambahkan pula variasi berat serbuk cangkang keong mas sesuai dengan perlakuan pertama. Setelah serbuk keong mas ditambahkan sesuai dengan variasi berat serbuk, maka kemudian larutan $10 \mathrm{ppm}$ merkuri yang ditambahkan serbuk diaduk menggunakan magnetic stirrer dengan kecepatan $100 \mathrm{rpm}$ selama 30 menit untuk tiap-tiap sampel. Setelah diaduk sesuai dengan waktu yang ditentukan, larutan didiamkan selama 24 jam [11]. Kemudian larutan yang telah didiamkan disaring menggunakan kertas saring [12]. Supernatant yang dihasilkan dianalisis dengan AAS untuk menentukan kadar logam $\mathrm{Hg}$. 


\section{Penentuan Efektivitas Penyerapan Logam}

Menurut ref. [13], efektivitas penyerapan logam berat dapat ditentukan dengan membandingkan konsentrasi logam mula-mula dengan konsentrasi logam setelah penyerapan, dengan persamaan berikut.

$$
E F=\frac{(Y i-Y f)}{Y i} \times 100 \%
$$

Dimana EF adalah efektivitas penurunan, Yi adalah konsentrasi logam mula-mula dan Yf adalah konsentrasi logam setelah penyerapan.

\section{Hasil dan Pembahasan}

\section{Efektivitas Penyerapan Logam Berat Hg dengan Waktu Pengadukan 15 Menit}

Penyerapan logam berat $\mathrm{Hg}$ dilakukan dengan memvariasikan massa serbuk keong mas serta waktu pengadukan. Massa serbuk keong mas dan waktu pengadukan merupakan salah satu faktor yang mempengaruhi proses adsorpsi [11]. Dalam proses pengadukan juga diatur kecepatan pengadukan. Kecepatan pengadukan yang digunakan adalah $100 \mathrm{rpm}$. Menurut ref. [11] mengatakan bahwa kecepatan $100 \mathrm{rpm}$ adalah kecepatan aduk yang efektif untuk adsorpsi. Hal ini dikarenakan jika digunakannya kecepatan aduk diatas $100 \mathrm{rpm}$ membuat ikatan adsorben dan logam terlepas sehingga adsorben tidak sempat membentuk ikatan yang kuat dengan logam. Bila digunakan kecepatan aduk dibawah $100 \mathrm{rpm}$ maka kemungkinan besar proses adsorpsi akan lambat. Hal ini dikarenakan partikel-partikel logam akan lama diserap oleh adsorben. Penggunaan serbuk cangkang keong mas sebagai adsorben dapat menurunkan konsentrasi Hg. Penurunan tersebut dapat dilihat pada Tabel 1.

Tabel 1. Hasil penyerapan $\mathrm{Hg}$ dengan waktu pengadukan 15 menit

\begin{tabular}{cccc}
\hline $\begin{array}{c}\text { Serbuk Keong Mas } \\
(\mathrm{g})\end{array}$ & Hasil Uji/(mg/l) & $\begin{array}{c}\text { Baku Mutu } \\
\text { (PP.No 42 tahun 2008) }\end{array}$ & $\begin{array}{c}\text { Efektivitas Penyerapan } \\
(\%)\end{array}$ \\
\hline 0 & 10 & 0,001 & 0 \\
5 & 0,027 & 0,001 & 99,73 \\
10 & 0,025 & 0,001 & 99,75 \\
15 & 0,023 & 0,001 & 99,77 \\
20 & 0,013 & 0,001 & 99,87 \\
\hline
\end{tabular}

Sumber: Hasil pengujian penelitian

Berdasarkan Tabel 1 dapat dilihat, bahwa pada massa 5 gr serbuk cangkang keong mas dapat menurunkan konsentrasi Hg 10 ppm menjadi 0,027 ppm. Pada massa 10 gr serbuk cangkang keong mas dapat menurunkan konsentrasi $\mathrm{Hg} 10 \mathrm{ppm}$ menjadi 0,025 ppm. Pada massa 15 gr serbuk cangkang keong mas dapat menurunkan konsentrasi $\mathrm{Hg} 10 \mathrm{ppm}$ menjadi $0,023 \mathrm{ppm}$. Hasil yang sedikit berbeda yaitu pada massa 20 gr serbuk cangkang keong mas, dimana hasil yang diperoleh yaitu 0,013 ppm. Perbedaan yang diperoleh tidak begitu signifikan karena masih berada pada baku mutu limbah tersebut. Menurut ref. [11] waktu pengadukan berbanding lurus dengan banyaknya artikel yang diserap, karena semakin lama waktu pengadukan maka partikel logam merkuri semakin banyak terserap. Pengaruh penambahan massa serbuk cangkang keong mas dan waktu pengadukan dapat dilihat pada Gambar 1 dan Gambar 2.

Berdasarkan Gambar 2 dapat dilihat bahwa nilai efektivitas penyerapan paling baik terjadi pada serbuk keong mas 20 gr. Semakin banyak massa ditambahkan maka semakin banyak pula jumlah partikel- partikel yang akan terkumpul pada adsorben [11]. Selain massa serbuk cangkang keong mas, waktu pengadukan juga mempengaruhi proses adsorpsi. Dimana menurut ref. [11] menjelaskan bahwa semakin lama waktu pengadukan, maka semakin banyak pula partikel yang terserap. Hal ini dikarenakan banyak partikel yang dapat diserap oleh adsorben. Akan tetapi, penggunaan waktu yang lama dalam pengadukan juga akan mempengaruhi hasil. Dalam ref. [14] dinyatakan bahwa ketika digunakan waktu pengadukan yang lama dalam penyerapan, maka pori-pori yang ada pada adsorben yang sudah penuh awalnya akan terbuka kembali, ini disebabkan oleh terlepasnya ion-ion logam yang terikat. Proses ini dikenal dengan desorpsi yaitu proses pelepasan ion, molekul atau atom yang terjadi pada permukaan adsorben. Peristiwa ini terjadi karena proses adsorpsi sudah terjadi secara maksimal, sehingga permukaan adsorben tidak mempunyai lagi kemampuan dalam menyerap ion, molekul maupun logam [15]. 


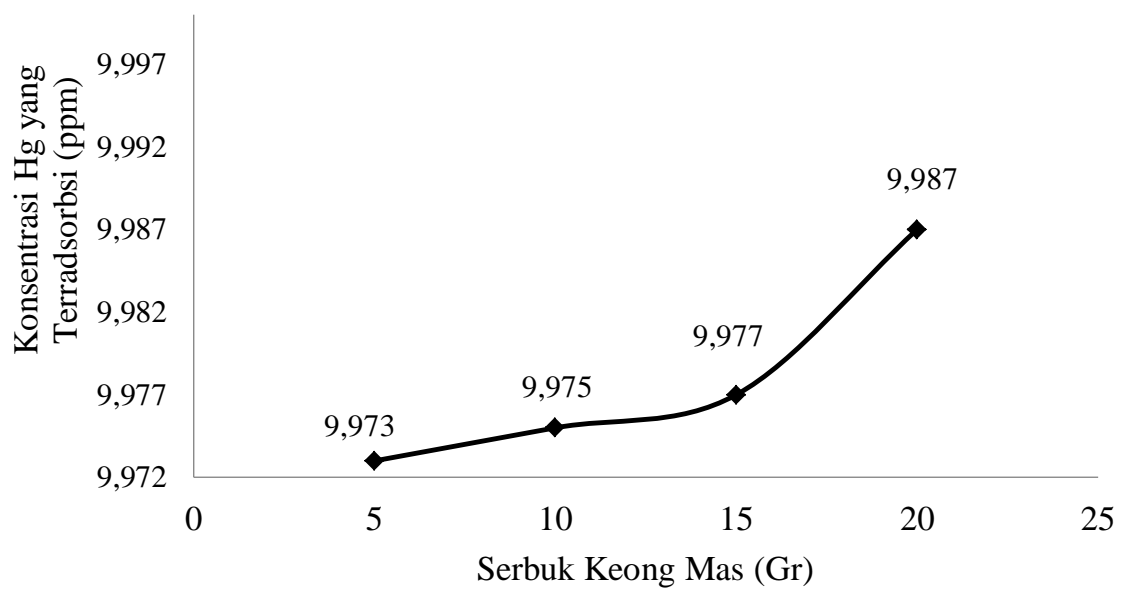

Gambar 1. Hasil uji penurunan $\mathrm{Hg} 10$ ppm dengan waktu pengadukan 15 menit Sumber: Hasil pengujian penelitian

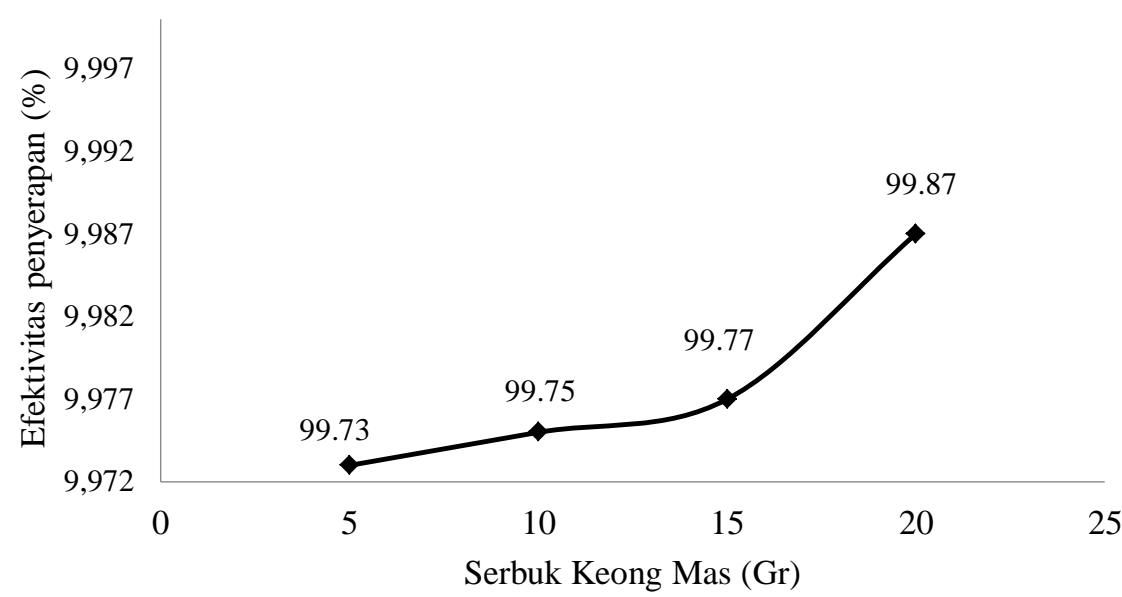

Gambar 2. Grafik efektivitas penyerapan hg dengan waktu pengadukan 15 menit Sumber: Hasil pengujian penelitian

\section{Efektivitas Penyerapan Logam Berat Hg dengan Waktu Pengadukan 30 Menit}

Efektivitas penyerapan $\mathrm{Hg}$ dengan waktu pengadukan 30 menit masih memvariasikan massa serbuk cangkang keong mas dalam perlakuannya. Hasil penurunan $\mathrm{Hg}$ dengan waktu pengadukan 30 menit dapat dilihat pada Tabel 2.

Tabel 2. Hasil penyerapan $\mathrm{Hg}$ dengan waktu pengadukan 30 menit

\begin{tabular}{cccc}
\hline $\begin{array}{c}\text { Massa Serbuk/ } \\
(\mathrm{gr})\end{array}$ & Hasil Uji/ (mg/l) & $\begin{array}{c}\text { Baku Mutu/ } \\
\text { (PP.No 42 tahun 2008) }\end{array}$ & $\begin{array}{c}\text { Efektivitas Penyerapan } \\
(\%)\end{array}$ \\
\hline 0 & 10 & 0,001 & 0 \\
5 & 0,048 & 0,001 & 99,52 \\
10 & 0,037 & 0,001 & 99,62 \\
15 & 0,036 & 0,001 & 99,64 \\
20 & 0,010 & 0,001 & 99,90 \\
\hline
\end{tabular}

Sumber: Hasil pengujian penelitian

Adapun untuk grafik hasil uji dan grafik hasil efektivitas penyerapan logam $\mathrm{Hg}$ dengan waktu pengadukan 30 menit dapat dilihat pada Gambar 3. 


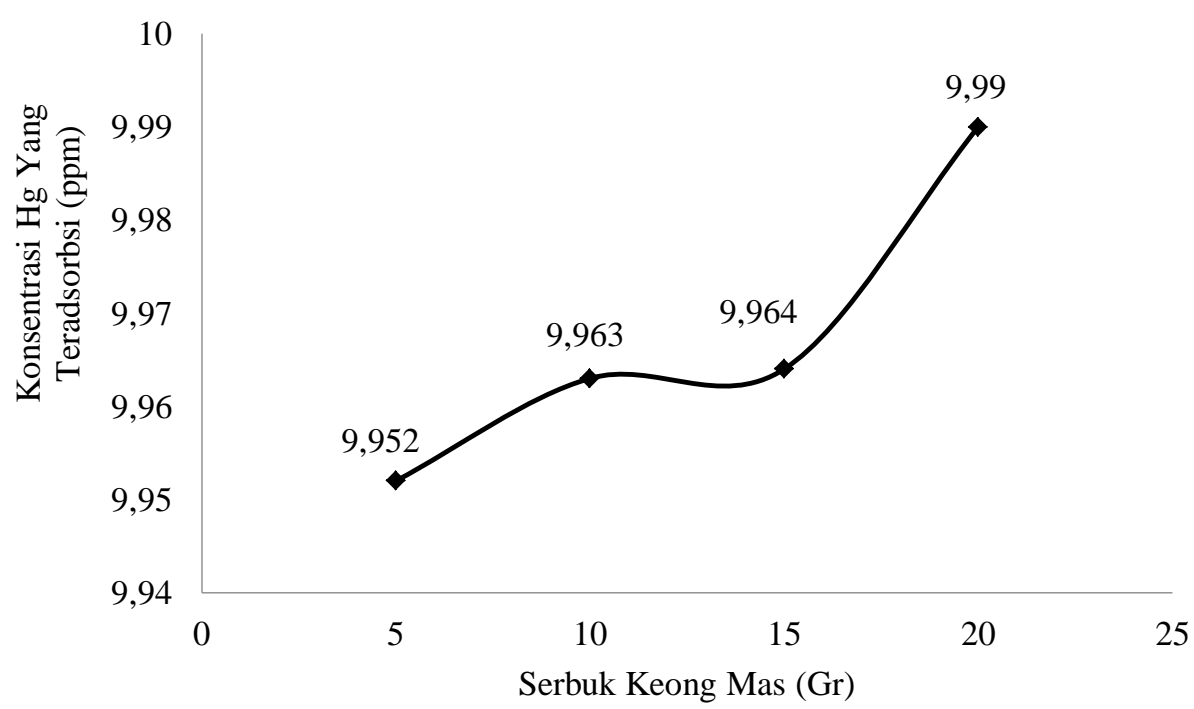

Gambar 3. Hasil uji penurunan $\mathrm{Hg} 10$ ppm dengan waktu pengadukan 30 menit efektifitas Sumber: Hasil pengujian penelitian

Sedangkan efektivitas penyerapan merkuri 10 ppm dengan waktu pengadukan 30 menit dapat dilihat pada Gambar 4.

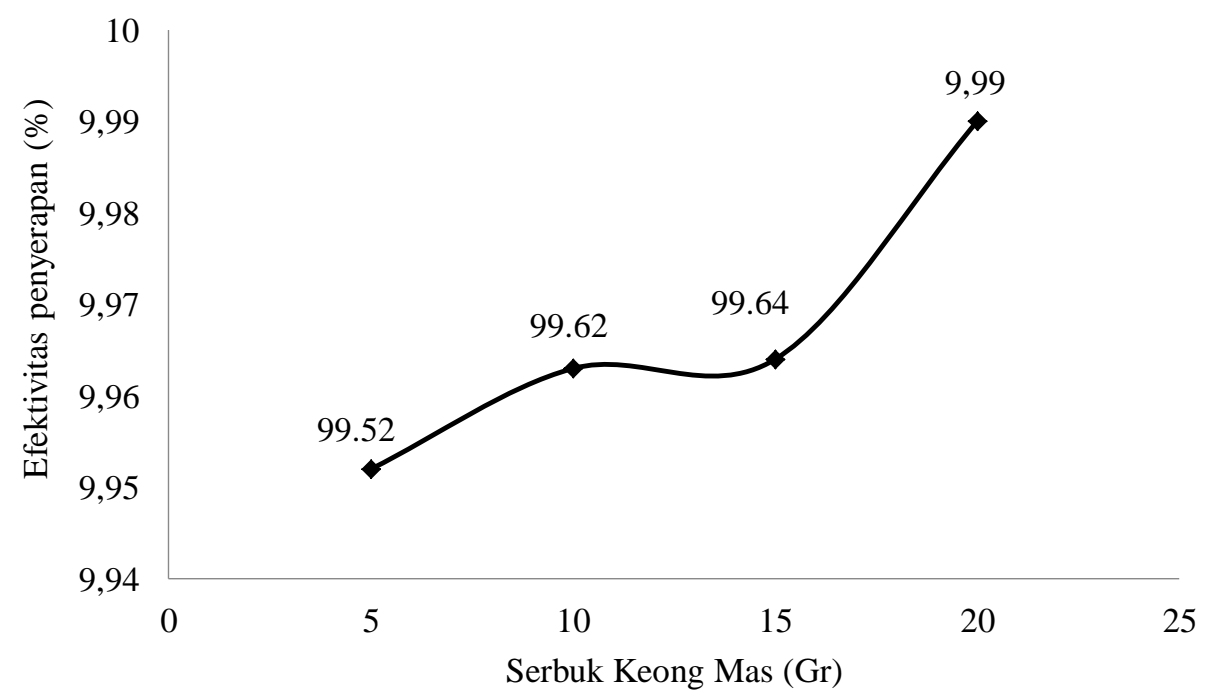

Gambar 4. Grafik efektivitas penyerapan $\mathrm{Hg}$ dengan waktu 30 menit Sumber: Hasil pengujian penelitian

Berdasarkan Gambar 4, dapat dilihat dengan jelas bahwa semakin banyak penambahan massa serbuk cangkang keong mas, konsentrasi $\mathrm{Hg} 10 \mathrm{ppm}$ semakin menurun. Menurut ref. [16] menjelaskan bahwa semakin bertambahnya jumlah adsorben yang digunakan maka konsentrasi logam yang terkandung akan semakin menurun. Pada penambahan serbuk cangkang keong mas 5 gr didapatkan hasil penurunan konsentrasi $\mathrm{Hg} 10 \mathrm{ppm}$ menjadi konsentrasi 0,048 ppm. Sedangkan pada massa serbuk cangkang keong mas 20 gr terjadi penurunan sedikit lebih banyak dibandingkan massa sebelumnya yaitu sebesar $0,010 \mathrm{ppm}$. Pada penyerapan $\mathrm{Hg}$ dengan waktu 30 menit penurunan terbesar juga terjadi pada massa 20 gr serbuk cangkang keong mas yaitu tingkat efektivitasnya sebesar $99,90 \%$.

\section{Kesimpulan}

Hasil penelitian menunjukkan bahwa serbuk cangkang keong mas mampu menurunkan logam merkuri $10 \mathrm{ppm}$ dengan hasil yang sangat baik. Nilai efektivitasnya penyerapannya mencapai 99,9\%. Nilai ambang baku mutu logam merkuri pada lingkungan menurut PP No.42 tahun 2008 adalah 0,001 mg/l. Hasil penurunan konsentrasi $\mathrm{Hg} 10$ ppm yang efektif terdapat pada kadar 20 gr serbuk keong mas dengan waktu pengadukan 30 menit yaitu 0,010 ppm. Pada kadar ini, serbuk keong mas mampu logam 
Hg $10 \mathrm{mg} / \mathrm{l}$ menjadi 0,010 mg/l. Kadar serbuk cangkang keong mas dan waktu pengadukan yang efektif dalam menyerap logam berat $\mathrm{Hg}$ adalah pada kadar 20 gr dengan waktu pengadukan 30 menit yaitu sebesar 99,90\%.

\section{Referensi}

[1] M.J. Kusnet, "Poisoning dan drug overdose," Mercury. London, 2013.

[2] Nonong, "Pemanfaatan Limbah Tahu sebagai Penyerap Logam Krom, Kadmium dan Besi dalam Air Lindi di TPA," Jurnal Pembelajaran Sains, (257-269), 2010.

[3] M. Tzesus dan B. Volesky, "The Mecanism of Uranium Biosorption by Rhyzopus arrhizus," Biotechnol Bioeng. (385-401), 1992.

[4] N.D. Pambudi, "Pengaruh Metode Pengolahan Terhadap Kelarutan Mineral Keong Mas (Pomacea canaliculata) dari Perairan Situ Gede, Bogor," Skripsi, 2011.

[5] S.R.S. Simaremare, "Perbedaan Kemampuan Cangkang Kepiting dengan Cangkang Udang sebagai Koagulan Alami dalam Penjernihan Air Sumur di Desa Tanjung Ibus Kecamatan Secanggang Kabupaten Langkat," Skripsi, Universitas Sumatera Utara, 2013.

[6] Islami dkk, "Potensi Abu Cangkang Keong Mas sebagai Adsorben Tembaga dalam Larutan," Laporan Penelitian FMIPA, Pekanbaru, Universitas Riau, 2014.

[7] Putri, "Pembuatan Kitosan dari Cangkang Keong Mas Untuk Absorben Fe pada Air Sumur," Skripsi, Surakan Fakultas Teknik Prodi D-III Teknik Kimia, 2014.

[8] A. Wiyarsi dan E. Priyambodo, Pengaruh Konsentrasi Kitosan dari Cangkang Udang Terhadap Efisiensi Penyerapan Logam Berat," Prodi Pendidikan Kimia, Fakultas FMIPA UNY, 2007.

[9] S. Utomo, "Pengaruh Waktu Aktivasi dan Ukuran Partikel terhadap Daya Serap Karbon Aktif dari Kulit Singkong dengan Aktivator NaOH," Seminar Nasional Sains dan Teknologi 2014, Fakultas Teknik, Universitas Muhammaddiyah Jakarta, 2014.

[10] SNI 6989.78:2011, Air dan Air Limbah: Cara Uji Raksa (Hg) secara Spektofotometri Serapan Atom (SSA) Uap Dingin atau Mercury Analyzer 2011.

[11] I. Syauqiah, M. Amalia, dan A. H. Kartini, "Analisis Variasi Waktu Kecepatan Pengaduk pada Proses Adsorpsi Limbah Logam Berat dengan Arang Aktif," Jurnal Info Teknik, (11), 2011.

[12] Y. Herlandien, "Pemanfaatan Arang Aktif sebagai Adsorben Logam Berat dalam Air Lindi Di TPA Pakusari Jember," Skripsi, Jurusan Kimia, Fakultas Matematika dan Ilmu Pengetahuan Alam Universitas Jember, 2013.

[13] A.I. Larasati, L.D. Susanawati, dan B. Suharto, "Efektivitas Adsorpsi Logam Berat pada Air Lindi menggunakana Media Karbon Aktif, Zeolit dan Silika Gel di TPA Tlekung, Batu", Jurnal Sumberdaya Alam dan Lingkungan, (44-48), 2015.

[14] A. Salasatun, W. Oktiawan, dan I.W. Wardhana, "Pengaruh Konsentrasi Activator NaOH dan Tinggi Kolom pada Arang Aktif dari Kulit Pisang terhadap Efektivitas Penurunan Logam Berat $\mathrm{Cu}$ dan Zn Limbah Cair Industri Elektroplatin,” Jurnal Teknik Lingkungan, (5), 2016.

[15] I. Purnamasari, "Adsorpsi-Desorpsi Monologam dan Multilogam Ion $\mathrm{Ni}, \mathrm{Cd}$, dan $\mathrm{Cu}$ oleh Material Biomassa Alga Nitzschia sp yang dimodifikasi dengan pelapisan Silika-Magnet," Skripsi, FMIPA, Bandar Lampung, 2016.

[16] Nurhasni, Hendrawati, dan N. Saniyyah, "Sekam Padi untuk Menyerap Ion Logam Tembaga dan Timbal dalam Air Limbah,” Jurnal Pemanfaatan Sekam Padi untuk Menyerap Ion Logam, (36-44), 2014. 